\title{
Differentiation Between Familial Mediterranean Fever Related Spondyloarthropathy and Ankylosing Spondylitis
}

\author{
Ailevi Akdeniz Ateşi İlişkili Spondiloartropati ile Ankilozan Spondilit Ayrımı
}

\author{
Gönen MENGİ, Ümit BİNGÖL, Nurten KÜÇÜKÇAKIR
}

Department of Physical Medicine and Rehabilitation, Medical Faculty of Uludag University, Bursa, Turkey

Familial Mediterranean fever (FMF) is an autosomal recessive autoinflammatory disease characterized by recurrent inflammatory attacks of the serosal and synovial membranes, with musculoskeletal involvement being encountered in $75 \%$ of the patients. ${ }^{[1]}$ The incidence of sacroiliitis is high, and spondyloarthropathy may also coexist. ${ }^{[1]}$

Ankylosing spondylitis (AS) is a chronic inflammatory disease involving the spine and sacroiliac joints. ${ }^{[1]}$ Although sacroiliitis in an FMF patient is suggestive of AS, FMF-related spondyloarthropathy should also be considered and differentiated. In the following example, we aim to emphasize the importance of distinguishing between these two conditions.

A 37-year-old female patient presented with localized, continuous, stabbing back and hip pain which had been occurring for 15 years. She had been diagnosed with FMF, and colchicine had been prescribed which decreased the frequency and severity of the attacks. In the following years, she was prescribed indomethacin and sulfasalazine with the diagnosis of AS. Sacroiliac compression tests were negative, but Patrick's test was positive on the left side. Chest expansion and Schober's lumbar measurements were 2.5 and $4 \mathrm{~cm}$, respectively. Low back flexion and extension ranges were normal but painful at the extremes. Chin-sternum and occiput-wall distances were normal. Peripheral arthritis was absent. Straight leg raising and femoral stretch tests were negative, and biochemical tests, complete blood count (CBC), and urinalysis were normal. The erythrocyte sedimentation rate (ESR) was $14 \mathrm{~mm} / \mathrm{h}$, and $\mathrm{C}$ reactive protein (CRP) was $0.48 \mathrm{mg} / \mathrm{dl}$ (0.01-0.82). The rheumatoid factor (RF) and human leukocyte antigen (HLA)-B27 were negative. Magnetic resonance imaging (MRI) disclosed sclerosis, contrast enhancement, and narrowing of the sacroiliac joints compatible with bilateral sacroiliitis. However, lumbar X-rays revealed minimal changes, indicating spondyloarthropathy in the spine.

The patient was hospitalized, and a physical therapy program was designed to alleviate her pain. Upon completion of the therapy, she was discharged with a prescription for indomethacin and colchicine.

It is known that Mediterranean fever (MEFV) gene mutations are associated with the etiopathogenesis of FMF. Some believe that MEFV mutations may change the response to inflammatory diseases and also contribute to the development of AS. ${ }^{[2]}$

Cosan et al. ${ }^{[3]}$ analyzed 193 AS patients and 103 healthy controls and concluded that MEFV mutations occur significantly more often in patients with AS. Akkoç et al. ${ }^{[4]}$ found that MEFV mutations are more frequent in AS patients when compared with RA patients and the healthy population. Our case was diagnosed via the detection of the homozygote MEFV (M694V) gene mutation

Received: February 22, 2012 Accepted: February 27, 2012

Correspondence: Gönen Mengi, M.D. Uludağ Üniversitesi Tıp Fakültesi Fiziksel Tıp ve Rehabilitasyon Anabilim Dalı, 16059 Nilüfer, Bursa, Turkey. Tel: +90 532 - 5264722 e-mail: gonenmengi@gmail.com 
together with the symptoms and findings related to FMF. The patient also met the modified New York criteria for the diagnosis of AS. The clinical findings of spondyloarthropathy usually follow other symptoms and findings of FMF, as was the case with our patient. ${ }^{[1]}$ It is likely that some factors in the pathogenesis of FMF lead to the development of spondyloarthropathy. Sacroiliac joint involvement, usually HLA-B27 negative, is more frequent in the FMF population. ${ }^{[5]}$ Moreover, the spine is less affected than the sacroiliac joint, as was seen in our case. For these reasons, FMF-related spondyloarthropathy seems like a more probable diagnosis for our patient. Familial Mediterranean fever and AS are two clinical conditions which show distinct features regarding symptoms, findings, treatment, monitoring, and prognosis. Therefore, diagnostic criteria to aid in the discrimination of these two different entities is necessary.

\section{Declaration of conflicting interests}

The authors declared no conflicts of interest with respect to the authorship and/or publication of this article.

\section{Funding}

The authors received no financial support for the research and/or authorship of this article.

\section{REFERENCES}

1. Balaban B, Yasar E, Ozgul A, Dincer K, Kalyon TA. Sacroiliitis in familial Mediterranean fever and seronegative spondyloarthropathy: importance of differential diagnosis. Rheumatol Int 2005;25:641-4.

2. Cinar M, Dinc A, Simsek I, Erdem H, Koc B, Pay S, et al. The rate and significance of Mediterranean fever gene mutations in patients with ankylosing spondylitis: a three-month, longitudinal clinical study. Rheumatol Int 2008;29:37-42.

3. Cosan F, Ustek D, Oku B, Duymaz-Tozkir J, Cakiris A, Abaci N, et al. Association of familial Mediterranean feverrelated MEFV variations with ankylosing spondylitis. Arthritis Rheum 2010;62:3232-6. doi: 10.1002/art.27683.

4. Akkoc N, Sari I, Akar S, Binicier O, Thomas MG, Weale $\mathrm{ME}$, et al. Increased prevalence of M694V in patients with ankylosing spondylitis: additional evidence for a link with familial mediterranean fever. Arthritis Rheum 2010;62:3059-63.

5. Akar S, Birlik M, Sari I, Onen F, Akkoc N. M694V mutation may have a role in susceptibility to ankylosing spondylitis. Rheumatol Int 2009;29:1259-60. 